\title{
The Regulatory Role of Patents in Innovative Health Research and Its Translation from the Laboratory to the Clinic
}

\author{
Dianne Nicol and Jane Nielsen
}

\subsection{INTRODUCTION}

Regulators must ensure that innovative health research is safe and undertaken in accordance with laws, ethical norms and social values, and that it is translated into clinical outcomes that are safe, effective and ethically appropriate. But they must also ensure that innovative health research and translation (IHRT) is directed towards the most important health needs of society. Through the patent system, regulators provide an incentive-based architecture for this to occur by granting a temporary zone of exclusivity around patented products and processes. Patents thus have the effect of devolving control over IHRT pathways to patentees and to those to whom patentees choose to license their patent rights.

The sage words of Stephen Hilgartner set the backdrop for this chapter: 'Patents do not just allocate economic benefits; they also allocate leverage in negotiations that shape the technological and social orders that govern our lives'. ${ }^{1}$ Patents have been granted for many - if not all of the major recent innovations in health research, from the earliest breakthroughs like recombinant DNA technology, the polymerase chain reaction, the Harvard Oncomouse and the BRCA gene sequences, through to a whole variety of viruses, monoclonal antibodies, receptors and vectors, thousands of DNA sequences, embryonic stem cell technology, intron sequence analysis, genome editing technologies and many more. ${ }^{2}$ These innovations have laid the foundations for whole new health research pathways, from basic research, through applied research, to diagnostic and therapeutic end points. ${ }^{3}$ Broad patent rights over these fundamental innovations give patentees the freedom to choose how these research pathways will be progressed. Essentially then, the patent grant puts patentees in a position to assert significant private regulatory control over IHRT.

The first part of this chapter outlines this regulatory role of patents in IHRT. The chapter then considers the ways in which patentees choose to use their patent rights in IHRT, and the scope for government intervention. The chapter then explores recent actions by patentees that indicate

${ }^{1}$ S. Hilgartner, 'Foundational Technologies and Accountability', (2018) American Journal of Bioethics, 18(12), 63-65.

2 Organisation for Economic Cooperation and Development, 'Key Biotechnology Indicators', (OECD, 2019), www .oecd.org/innovation/inno/keybiotechnologyindicators.htm; Nuffield Council on Bioethics, 'The Ethics of Patenting DNA', (Nuffield Council on Bioethics, 2002), 39-44; D. Nicol, 'Implications of DNA Patenting: Reviewing the Evidence', (2011) Journal of Law, Information and Science 7, 21(1).

3 J. P. Walsh et al., 'Effects of Research Tool Patents and Licensing on Biomedical Innovation' in W. M. Cohen and S. A. Merrill (eds), Patents in the Knowledge-Based Economy (The National Academies Press, 2003), pp. 285-340, see particularly pp. $332-335$. 
a willingness to moderate the use of their patent rights by engaging in self-regulation and other forms of collaborative regulation. Finally, the chapter concludes with a call for greater government oversight of patent use in IHRT. Although self-regulation has merit in the absence of clear governmental direction, it is argued that private organisations should not have absolute discretion in deciding how to employ their patents in areas such as health, but that they must be held to account in exercising their state-sanctioned monopoly rights.

\subsection{PATENTS AS A FORM OF PRIVATE REGULATION}

In many markets, the regulation of market entry, prices, product availability and development is left to the market to varying degrees, there being at least some general consensus that competitive decision-making is a hallmark of market efficiency. ${ }^{4}$ At the same time, granting patent rights removes an element of competition from a market in order to induce innovation and disclosure. $^{5}$ While it is unclear how much innovation is optimal, it has been suggested that there is unlikely to ever be too much from an economic welfare perspective. ${ }^{6}$

Although primary innovators are arguably best placed to organise and control follow-on innovation, ${ }^{7}$ vesting decision-making power in a single private entity has the potential to scuttle efficiency in much the same way as absolute government control. Nonetheless, conferring this power on individual entities through the grant of patents - and accompanying Intellectual property (IP) rights - is generally justified on efficiency grounds. ${ }^{8}$ However, non-efficiency goals such as distributive fairness may also be important drivers of private regulatory arrangements and may be incorporated either consciously or unconsciously in regulatory schemes. ${ }^{9}$

Granting a patent gives a property right in an invention. As Mark Lemley observes, IP constitutes both a form of government regulation and a property right around which parties can contract, ${ }^{10}$ and its confused identity partly explains why policy makers have grappled with exactly how to manage the delicate innovation balance. Studies have provided mixed evidence as to the necessity to grant IP rights: in some technology areas, patents are viewed as necessary in order to recoup research and development investment, but this is by no means universal. ${ }^{11}$

${ }^{4}$ F. M. Scherer and D. Ross, Industrial Market Structure and Economic Performance (Boston: Houghton Mifflin, 1990), p. 660; K. J. Arrow, 'Economic Welfare and the Allocation of Resources for Invention' in The National Bureau of Economic Research (eds), The Rate and Direction of Inventive Activity: Economic and Social Factors (Princeton University Press, 1962),pp. 6o9-626.

5 R. P. Merges, Justifying Intellectual Property (Cambridge, MA: Harvard University Press, 2011), p. 27; R. Mazzoleni and R. R. Nelson, 'Economic Theories about the Benefits and Costs of Patents', (1998) Journal of Economic Issues, 32(4), 1031-1052, 1039.

6 Federal Trade Commission, "To Promote Innovation: The Proper Balance of Competition and Patent Law and Policy', (FTC, 2003), ch 2, their nzo.

7 E. Kitch 'The Nature and Functions of the Patent System', (1977) Journal of Law and Economics, 20(2), 265-290; R. P. Merges, 'Of Property Rules, Coase, and Intellectual Property', (1994) Columbia Law Review, 94(8), 2655-2673, 2661; M. A. Lemley, 'Ex Ante versus Ex Post Justifications for Intellectual Property', (2004) University of Chicago Law Review, 71(1), 129-149.

8 R. Feldman, 'Regulatory Property: The New IP,' (2016) Columbia Journal of Law E the Arts, 40(1), 53-103; F. K. Hadfield, 'Privatising Commercial Law', (2001) Regulation, 24(1), 40-45, 44; O. Feeney et al., 'Patenting Foundational Technologies: Lessons from CRISPR and Other Core Biotechnologies', (2018) The American Joumal of Bioethics, $18(12), 36-48$.

9 S. L. Schwarcz, 'Private Ordering', (2002) Northwestern University Law Review, 91(1) 319-350.

${ }^{10}$ M. Lemley, 'The Regulatory Turn in IP', (2013) Harvard Journal of Law and Public Policy, 36(1), $109-115$.

${ }^{11}$ R. Levin et al., 'Appropriating the Returns From Industrial Research and Development', (1987) Brookings Papers on Economic Activity: Microeconomics, 3, 783-831; W. Cohen et al., 'Protecting Their Intellectual Assets: Appropriability Conditions and Why US Manufacturing Firms Patent (or Not)', (2000), Working Paper No. 7552, National Bureau of 
The value of patents in IHRT has not been unequivocally established, although there is some evidence to suggest they are crucial for signalling purposes. ${ }^{12}$ Patent law can be said to form a 'corrective' function in the health context, particularly in relation to pharmaceuticals and biotechnology, where the development of clinical products is subject to substantial regulation. ${ }^{13}$ Without patents, it is argued that researchers would not commit the considerable investment required to conduct research with the ultimate aim of a clinical outcome.

\section{$14 \cdot 3$ USE OF PATENT RIGHTS IN INNOVATIVE HEALTH RESEARCH AND TRANSLATION}

Patentees can limit who enters a field by choosing who, if anyone, they will authorise to use their patents. This can create problems for broad breakthrough technologies, where insistence on exclusivity gives patentees and their licensees control over whole research pathways, allowing them to dictate how those pathways develop. Patentees and their licensees could choose to block others completely from using the technology, or restrict access, or charge excessive prices for use. Conversely, they could allow their patented technology to be used widely for minimal costs. The tragedy of the anticommons posited by Michael Heller and Rebecca Eisenberg, adds further complexity, speculating that a proliferation of patents in particular areas of technology exacerbates the problem because no one party has an effective privilege of use. ${ }^{14}$ Rather, agreement with multiple patentees would be required in order to utilise a particular resource.

Fortunately, empirical studies have revealed little evidence of blocking or anticommons effects in IHRT, ${ }^{15}$ suggesting that, on the whole, working solutions employed by researchers have allowed them to work around 'problematic' patents so that research and development may progress. 'Working solutions' mean strategies such as entering into licence agreements or other collaborative arrangements; inventing around problematic patents; relying on research exemptions; or challenging the validity of patents. ${ }^{16}$ These working solutions can be viewed as facets of the regulatory scheme that encompasses the grant of patent rights. However, solutions that involve entering into a licence agreement or other collaborative arrangement also involve a degree of conformity on the part of a patentee. It may be fruitless to approach a patentee unless they are willing to negotiate, which takes time and effort on their part, as well as on the part of the licensee. Unless these processes can be streamlined, the incentive to license is low.

\subsection{SCOPE FOR GOVERNMENT INTERVENTION}

Arguably, the fruits of all health-related research should be distributed openly, because of its vital social function of improving healthcare. However, this is hardly a realistic option for aspects such as drug development, where the enormous cost of satisfying regulatory requirements for

Economic Research. See also E. Mansfield, 'Patents and Innovation: An Empirical Study', (1986) Management Science, 32(2), 173-181.

${ }^{12}$ E. Burrone, 'Patents at the Core: The Biotech Business', (WIPO, 2006), www.wipo.int/sme/en/documents/patents biotech_fulltext.html.

${ }^{13}$ Lemley, 'The Regulatory Turn in IP'.

${ }^{14}$ M. A. Heller and R. S. Eisenberg, 'Can Patents Deter Innovation? The Anticommons in Biomedical Research', (1998) Science, $280(5364), 698-701$.

${ }^{15}$ Walsh et al., 'Effects of Research Tool Patents and Licensing', pp. 285, 335; D. Nicol and J. Nielsen, 'Patents and Medical Biotechnology: An Empirical Analysis of Issues Facing the Australian Industry', (2003) Occasional Paper

Series (6) Centre for Law and Genetics, 174-193; but note R. S. Eisenberg, 'Noncompliance, Nonenforcement, Nonproblem? Rethinking the Anticommons in Biomedical Research', (2008) Houston Law Review, 45(4), 1059-1099.

${ }_{16}$ Nicol and Nielsen, 'Patents and Medical Biotechnology', 208-225. 
marketing approval must be recoverable. For other aspects of IHRT, however, the case for more open access is compelling, particularly since it generally originates in public research laboratories, funded by governments from the public purse. ${ }^{17}$ Yet the ensuing patents may ultimately be controlled by private parties, whether spin-offs or more established firms. This phenomenon has been referred to by Jorge Contreras and Jacob Sherkow as 'surrogate licensing. ${ }^{8}$

Given the public contribution made to IHRT, the argument for open access, at least for research purposes, is appealing. Public funders are within their rights to insist on some form of open dissemination in such circumstances. ${ }^{19}$ But what are the options when patentees or their licensees insist on exclusivity, even for the most fundamental research tools? If governments see patents as providing a broader social function beyond giving monopoly rights to patentees albeit temporary in nature - they must ensure that, along with incentives to innovate, the patent system provides appropriate incentives to disseminate innovative outputs, or other regulatory mechanisms to compel the provision of access where needed. ${ }^{20}$ Patents provide patentees with significant freedom to decide who can enter a particular field of research, and what they can do. Some jurisdictions do have legislative provisions allowing government or private providers to step in should patentees fail to work the invention. ${ }^{21}$ Most countries exempt from infringement the steps needed for regulatory approval of generic pharmaceuticals and other chemicals. ${ }^{22}$ Some also exempt use of the patent for experimental purposes, although the scope of protected experimental use remains unclear. ${ }^{23}$ However, the reality is that the role of governments in regulating patent use is limited.

\subsection{EMERGENT SELF-REGULATORY MODELS FOR USE OF PATENT RIGHTS IN INNOVATIVE HEALTH RESEARCH AND TRANSLATION}

Recognising these limitations on government control of patent use, some promising developments are emerging in IHRT that indicate that patentees and their licensees are willing to consider a range of self-regulatory models in ensuring optimal patent utilisation. Some of the more prominent examples are discussed below.

\subsubsection{Non-exclusive Research Tool Licensing}

Because foundational research tools are just that - foundational to whole new areas of research best practice dictates they should be licensed non-exclusively. US funding agencies and

${ }^{17}$ L. Pressman et al., 'The Licensing of DNA Patents by US Academic Institutions: An Empirical Study', (2006) Nature Biotechnology, 24(1), 31 .

${ }^{18}$ J. L. Contreras and J. S. Sherkow, 'CRISPR, Surrogate Licensing, and Scientific Discovery', (2017) Science, 355(6326), 698-700; J. S. Sherkow, 'Patent Protection for CRISPR: An ELSI Review', (2017) Journal of Law and the Biosciences, $4(3), 565-576,570-571$.

19 A. K. Rai and B. N. Sampat, 'Accountability in Patenting of Federally Funded Research', (2012) Nature Biotechnology, 30(10), 953-956; K. J. Egelie et al., 'The Ethics of Access to Patented Biotech Research Tools from Universities and Other Research Institutions,' (2018) Nature Biotechnology, 36(6), 495

${ }^{20}$ Referred to by some commentators as 'carrots' and 'sticks'; see e.g. I. Ayres and A. Kapczynski, 'Innovation Sticks: The Limited Case for Penalizing Failures to Innovate’, (2015) University of Chicago Law Review, 82(4), 1781-1852.

${ }^{21}$ For example, US: 28 USC \ 1498(a) (government use) (2011); Australia: Patents Act 1990 (Cth) section 133 (compulsory licensing), section 163 (government use).

${ }^{22}$ For example, US: Roche Products Inc. v. Bolar Pharmaceuticals Co., 733 F.2d 858 (Fed. Cir. 1984), 35 USC $\left.\int 271(\mathrm{e})(1)\right)$; Patents Act 1990 (Cth) sections $119 \mathrm{~A}$ and $119 \mathrm{~B}$.

23 R. Dreyfuss, 'Protecting the Public Domain of Science: Has the Time for an Experimental Use Defense Arrived?', (2004) Arizona Law Review, 946(3), 457-472; K. J. Strandburg, 'What Does the Public Get? Experimental Use and the Patent Bargain', (2004) Wisconsin Law Review, 2004(1), 81-155. 
universities agree; for example, the US National Institutes of Health released guidance to this effect in 1999 and 2005. ${ }^{24}$ In 2007, the Association of University Technology Managers, recognising that 'universities share certain core values that can and should be maintained to the fullest extent possible in all technology transfer agreements', provided nine key points to consider in licensing university patents. Point 5 recommends 'a blend of field-exclusive and non-exclusive licenses'. ${ }^{25}$

Yet non-exclusive licensing is not cost-free. The problem that it presents to users is that it imposes a fee in return for not being sued for infringement, with little or no additional benefit for the user. ${ }^{26}$ Inclusion of reach through rights to future uses adds to the burden on follow-on researchers. ${ }^{27}$ If governments were really concerned about the toll of research tool patent claims on IHRT they could choose to exclude them, or to require them to be exchanged through some form of statutory licensing scheme, with minimal or no licensing fees and no other restrictive terms. For now, however, governments seem content to leave such decisions to patentees.

We are witnessing some interesting developments in this area, illustrating that government intervention may not yet be necessary. Companies like Addgene and the Biobricks Foundation have been established as intermediaries to facilitate no-cost, non-exclusive patent licensing and sharing of research materials for genome editing and synthetic biology research, respectively. ${ }^{28}$ There are also other examples of these types of intermediary arrangements, or 'clearinghouses' as they are sometimes called, in IHRT. Such arrangements appear to provide a valuable social function provided that fees are not excessive and that technology that is of real value to IHRT is included, so that the clearinghouse does not become a 'market for lemons'. ${ }^{29}$

\subsubsection{Mixed Licensing Models}

Realistically, a more nuanced approach over the simple choice of exclusive or non-exclusive licensing is needed, involving a mix of licensing strategies for a single patented technology. Licensing of the clustered regularly interspersed palindromic repeats (CRISPR) patents illustrates this point. CRISPR, as explained in Chapter 34, is a genome editing technology that has captivated the research world because of its ease of use and enhanced safety, owing to reduced incidence of off-target effects. ${ }^{30}$

${ }^{24}$ US Department of Health and Human Services, National Institutes of Health, 'Principles and Guidelines for Recipients of NIH Research Grants and Contracts on Obtaining and Disseminating Biomedical Research Resources: Final Notice', (1999) Federal Register 72090, 64(246); US Department of Health and Human Services, National Institutes of Health, 'Best Practices for the Licensing of Genomic Inventions: Final Notice', (2005) Federal Register 18413, 70(68); see also Organisation for Economic Co-Operation and Development, 'Guidelines for the Licensing of Genetic Inventions', (OECD, 2006).

${ }^{25}$ Association of University Technology Managers, 'In the Public Interest: Nine Points to Consider in Licensing University Technology', (Association of University Technology Managers, 2007), www.autm.net/AUTMMain/ media/Advocacy/Documents/Points_to_Consider.pdf.

${ }^{26}$ A. D. So et al., 'Is Bayh-Dole Good for Developing Countries? Lessons from the US Experience', (2008) PLoS Biology, 6(10), ez6z.

${ }^{27}$ J. Nielsen, 'Reach-Through Rights in Biomedical Patent Licensing: A Comparative Analysis of their Anti-Competitive Reach', (2004) Federal Law Review, 32(2), 169-204.

${ }_{28}$ J. Nielsen et al., 'Provenance and Risk in Transfer of Biological Materials', (2018) PLoS Biology, 16(8), ez2006031

29 E. van Zimmeren et al., 'Patent Pools and Clearinghouses in the Life Sciences', (2011) Trends in Biotechnology, 29(11), 569-576; see also D. Nicol et al., 'The Innovation Pool in Biotechnology: The Role of Patents in Facilitating Innovation', (2014) Centre for Law and Genetics Occasional Paper No. 8. 249-250.

$3^{\circ}$ V. Iyer et al., 'No Unexpected CRISPR-Cas9 Off-target Activity Revealed by Trio Sequencing of Gene-edited Mice', (2018) PLoS Genetics, 14(7), p. e1007503. 
Already, we are witnessing the adoption of nuanced approaches for licensing CRISPR patents. For example, the Broad Institute, one of the giants of CRISPR technology, non-exclusively licences CRISPR constructs freely for public sector research through Addgene, and charges a fee for use in more commercially-oriented research. Broad exclusively licences to its own spin-off company, Editas, for therapeutic product development. Broad describes this as an inclusive innovation model'. ${ }^{31}$ However, this model has been criticised by Oliver Feeney and colleagues on the basis that the decision whether to allow other uses for therapeutic purposes is left to Editas. ${ }^{32}$ They see this as a 'significant moral hazard', because of the potential restrictions it imposes on therapeutic development. While Feeney and colleagues propose governmentimposed time limitations on exclusivity as a means of addressing such hazards, it is doubtful, given past history, that governments would be persuaded to incorporate this level of post-grant regulatory intervention within the patent system.

Knut Egelie and colleagues, equally concerned about CRISPR patent licensing, argue that public research organisations should commit more fully to a self-regulatory model that balances social responsibilities with commercial activity. ${ }^{33}$ Their 'transparent licensing model' would minimise fees and other restrictions for uses of patented subject matter as research tools, and narrow field-of-use exclusive licences for commercial development. They suggest government intervention as an alternative to this self-regulatory model, referring to some of the recently emerging contractual funding strategies in Europe. However, they themselves criticise both options, the former for lacking public control and the latter for over-regulation and unnecessary bureaucracy. More cooperative and collaborative strategies, involving both public sector and private sector organisations, might provide alternative models.

\subsubsection{Collaborative Licensing}

A greater commitment to social responsibility might be achieved by patentees and their licensees through entry into collaborative IP arrangements. ${ }^{34}$ Patent pools have been used in some high technology areas - particularly information technology - to overcome patent thickets and cluttered patent landscapes. ${ }^{35}$ In IHRT, however, complex arrangements such as patent pools have gained limited traction, ${ }^{36}$ primarily because of the lack of need to date. Simpler strategies

${ }^{31}$ Broad Institute, 'Information About Licensing CRISPR Genome Editing Systems', (Broad Institute, 2017), www .broadinstitute.org/partnerships/office-strategic-alliances-and-partnering/information-about-licensing-crispr-genome-edi.

$3^{2}$ Feeney et al., 'Patenting Foundational Technologies', 40.

33 K. J. Egelie et al., 'The Emerging Patent Landscape of CRISPR-Cas9 Gene Editing Technology', (2016) Nature Biotechnology, 3(10), 1025.

34 A. Krattiger and S. Kowalski, 'Facilitating Assembly of and Access to Intellectual Property: Focus on Patent Pools and a Review of other Mechanisms' in A. Krattiger et al. (eds), Intellectual Property Management in Health and Agricultural Innovation: A Handbook of Best Practices (MIHR, Oxford UK and PIPRA Davis California, US, 2007) p. 131; P. Gaulé, 'Towards Patents Pools in Biotechnology?', (2006) Innovation Strategy Today, 2, 123; G. Van Overwalle et al., 'Models for Facilitating Access to Patents on Genetic Inventions', (2006) Nature Reviews Genetics, 7(2), 143; van Zimmeren et al., 'Patent Pools and Clearinghouses'; Organisation for Economic Cooperation and Development, 'Collaborative Mechanisms for Intellectual Property Management in the Life Sciences', (OECD, 2011); Nicol et al., 'The Innovation Pool'.

35 R. P. Merges, 'Institutions for Intellectual Property Transactions: The Case of Patent Pools' in R. C. Dreyfuss et al. (eds), Expanding the Boundaries of Intellectual Property: Innovation Policy for the Knowledge Society (Oxford University Press; 2001), ch 6.

${ }^{3}$ E. van Zimmeren et al., Patent Licensing in Medical Biotechnology in Europe: A Role for Collaborative Licensing Strategies? (Catholic University of Leuven Centre for Intellectual Property Rights; 2011), 82; Nicol et al., "The Innovation Pool', 238-239, 250. 
such as non-exclusive licensing and clearinghouses appear to be adequate at the present time, and predicted anticommons effects have not yet emerged. ${ }^{37}$

Where patentees are reluctant to engage in collaborative strategies, there is some scope to mandate engagement. Patent pools, for example, have in some instances - especially in the USA - been established by government regulators in order to ease innovative burdens and address competition law concerns. ${ }^{3}$ Mandatory arrangements are rarely optimistically embraced, and prospects for the sustainability of collaborative arrangements is probably significantly greater where they are voluntary. Patent pools are complex structures and involve many legal considerations. Although there has been some success in establishing patent pooling-type arrangements in public health emergencies like HIV/AIDS and other epidemics, ${ }^{39}$ it is difficult to see what would motivate patentees to come together to create such complex structures in IHRT at the present time, particularly given the rapid pace of technological development and change.

Patent aggregation is another increasingly popular strategy, referring to the process of collecting suites of IP required to conduct research and development within a particular field of use. The process of patent aggregation has brought with it some negative press, because of concerns that aggregators could be 'patent trolls', whose sole motivation is extracting licensing revenue. ${ }^{40}$ However, not all aggregators have this trolling motivation, but rather license out entire bundles of patents on a non-exclusive basis. To this extent, their role in advancing the research agendas in IHRT can be seen as broadly facilitative. ${ }^{41}$

\subsubsection{Ethical Licensing}

Aside from the social good associated with self-regulatory models of patent use discussed above, there are other ethical and social considerations that could be addressed through more publicfocused approaches to licensing. For example, even where public sector organisations exclusively license to private partners, whether spin-offs or established firms, it is common practice for the license terms to reserve rights for the organisation's researchers to continue to conduct research using patented subject matter. ${ }^{42}$ Reservation of the right to engage in broader sharing of patented subject matter for non-commercial research purposes might also be included in such agreements, effectively circumventing the lack of a statutory or common law research exemption in some jurisdictions.

Patent pledges and non-assertion covenants can be used to serve essentially the same purpose. ${ }^{43}$ The role of reservation of rights could also extend to humanitarian uses, which has been

37 Gaulé, ‘Towards Patents Pools in Biotechnology?', 123, 129; Nicol et al., 'The Innovation Pool', 238.

$3^{8}$ D. Serafino, 'Survey of Patent Pools Demonstrates Variety of Purposes and Management Structures', (2007) KEI Research Note 6, www.keionline.org/book/survey-of-patent-pools-demonstrates-variety-of-purposes-and-managementstructures.

39 UNITAID, 'The Medicines Patent Pool', (UNITAID), www.unitaid.org/project/medicines-patent-pool/\#en.

$4^{\circ}$ M. A. Lemley, 'Are Universities Patent Trolls?', (2008) Fordham Intellectual Property, Media and Entertainment Law Journal, 18(3), 611-631; A. Layne-Farrar and K. M. Schmidt, 'Licensing Complementary Patents: "Patent Trolls", Market Structure, and “Excessive” Royalties', (2010) Berkeley Technology Law Journal, 25(2), 1121.

$4^{11}$ A. Wang, 'Rise of the Patent Intermediaries', (2010) Berkeley Technology Law Journal, 25(1), 159, 167, 173.

$4^{2}$ A. B. Bennett, 'Reservation of Rights for Humanitarian Uses' in A. Krattiger et al. (eds), Intellectual Property Management in Health and Agricultural Innovation: A Handbook of Best Practices (Oxford, UK: MIHR; and Davis, USA: PIPRA; 2007), p. 41.

43 J. Contreras, 'Patent Pledges', (2015) Arizona State Law Journal, 47(3), 543-608; A. Krattiger, 'The Use of Nonassertion Covenants: A Tool to Facilitate Humanitarian Licensing, Manage Liability, and Foster Global Access' in A. Krattiger et al. (eds), Intellectual Property Management in Health and Agricultural Innovation: A Handbook of Best Practices, (Oxford, UK: MIHR; and Davis, USA: PIPRA; 2007), p. 739. 
mooted specifically in the context of agricultural biotechnology. As Alan Bennett notes, these voluntary measures can serve the purpose of meeting the humanitarian and commercial needs of developing countries in the absence of national policies to this effect. ${ }^{44}$ Such measures could be equally effective in the context of humanitarian uses of innovative health technologies, an area which likewise suffers from a lack of clear government policy direction.

There has been recent discussion on the efficacy of introducing ethical terms into patent licences for the new genome editing technologies, particularly CRISPR. The emergence of this technology triggered a range of ethical debates in relation to its applications in agriculture, the natural environment - for example, in pest eradication through a combination of CRISPR and gene drives - and humans - for example, in genetic enhancement, germline genome modification and gene editing research using human embryos. ${ }^{45}$

The Broad Institute, through Editas, and other public research organisations and their licensees, are already using licences that exclude these types of ethically questionable uses, whether in human or non-human contexts. As Christi Guerrini and colleagues note, there are some obvious advantages with this approach, including that: licence terms are enforceable; they can be tailored; and they are negotiated, leading to better buy in. ${ }^{6}$ Given that the regulation of genome editing varies widely across jurisdictions, ${ }^{47}$ the introduction of ethical licensing terms also has the advantage of creating enforceable obligations across the jurisdictions where the patent has been granted and where the licence applies. Potentially, then, ethical licences could impose global standards on uses of CRISPR technology, which is otherwise considerably conjectural if relying on agreement between countries.

Despite the apparent attractiveness of ethical licensing, however, there is likely to be some unease with the notion of devolving decisions about what is or is not ethical to patentees. ${ }^{4}$ In areas such as this, which are highly contentious, community consensus would usually be a precursor to government regulation. Is regulatory failure in this area significant enough to justify private action? Is this a step too far when it amounts to ceding regulation to private entities?

\subsection{CONCLUSION}

Patents play a key role in the progress of IHRT. By granting patents, governments devolve to patentees considerable decision-making power about who can enter particular fields of IHRT and what they can do. This chapter has shown that patentees can and do choose to exercise this power wisely, by engaging in open and collaborative models for patent use. However, not all choose do so, and governments currently have limited regulatory tools with which to compel such engagement.

Patentees can decide to work collaboratively with other interested parties, or not. They can decide whether to share broadly, or not. They can even decide what types of uses are ethical or unethical. This is a significant set of delegated powers. Regulators have at their disposal various policy levers that could provide them with broad discretion to specify criteria for patent

\footnotetext{
44 Bennett, 'Reservation of Rights'.

45 Sherkow, 'Patent Protection for CRISPR', 565-576, 572-573.

$4^{6}$ C. J. Guerrini et al., 'The Rise of the Ethical License', (2017) Nature Biotechnology, 25(1), 22; Sherkow, 'Patent Protection for CRISPR'.

47 R. Isasi et al., 'Editing Policy to Fit the Genome?', (2016) Science, 351(6271), 337-339.

$4^{8}$ N. de Graeff et al., 'Fair Governance of Biotechnology: Patents, Private Governance, and Procedural Justice', (2018) American Journal of Bioethics, 18(12), 57-59, 58 .
} 
eligibility, periods of exclusivity and access. ${ }^{49}$ Regulatory control can be asserted by governments both pre-grant, influencing the ways in which patents are granted, and post-grant, on the ways in which patents are used. Governments can use these regulatory tools to impose limits on these delegated powers, but these are not being fully utilised at present.

The current situation is that non-enforceable guidelines have been issued in some jurisdictions to assist patentees in deciding how to exercise their powers, but not in others. Internationally, although the OECD has issued licensing guidelines, ${ }^{\circ}$ for the most part there is no jurisdictional consensus on how best to set limits on the exercise of patent rights. This is not surprising in view of the diversity of technologies and actors involved and given jurisdictional discrepancies. More research is needed to assist governments in finding optimal ways to support, guide and regulate public research organisations and private companies in their use of the patent system in IHRT.

\section{ACKNOWLEDGEMENTS}

The research presented in this chapter is supported by funding from the Australian Research Council, DP180101262.

49 D. L. Burk and M. A. Lemley, 'Policy Levers in Patent Law', (2003) Virginia Law Review, 89(7), 1575-1696.

$5^{\circ}$ OECD, 'Recommendation of the Council on the Licensing of Genetic Inventions', (OECD/LEGAL/0342, 2007). 